\title{
Toxicological Evaluation of Ethanol Extract of Adenium obesum Stem Bark in African Catfish, Clarias gariepinus
}

\section{*11SAMSON ENEOJO ABALAKA; MUHAMMAD YAKASAI FATIHU; NAJUME DOGUWAR GIGINYA IBRAHIM; SULEIMAN FOLORUNSHO AMBALI}

\author{
${ }^{l}$ Department of Veterinary Pathology, Ahmadu Bello University, Zaria, Nigeria. \\ ${ }^{2}$ Department of Veterinary Pharmacology and Toxicology, Ahmadu Bello University, Zaria, Nigeria.
}

\begin{abstract}
KEY WORDS: Adenium obesum, Clarias gariepinus, toxicity, median lethal concentration
\end{abstract}
\begin{abstract}
The toxicity of ethanol extract of Adenium obesum stem bark as a tool for aquaculture pond management prior to the stocking of desired fish species was evaluated in Clarias gariepinus over a 96-h exposure. The fish were exposed to $6.25 \mathrm{mgL}^{-1}, 7.50 \mathrm{mgL}^{-1}$, $8.20 \mathrm{mgL}^{-1}, 8.80 \mathrm{mgL}^{-1}$ and $10.00 \mathrm{mgL}^{-1}$ of the extract and a control in an acute static toxicity bioassay after performing a range finding test to determine the median lethal concentration $\left(\mathrm{LC}_{50}\right)$ of the extract. Exposed fish showed signs of changed behaviours with adaptive responses, respiratory distress and nervous compromise, including mortality in some of the exposed fish. The appearance and intensities of the observed signs were concentration and exposure period-dependent. An $\mathrm{LC}_{50}$ value of $7.35 \mathrm{mgL}^{-1}$ was established for the extract in the exposed fish where mean mortality was significantly $(\mathrm{p}<0.05)$ concentration and exposure period-dependent. The toxic nature of the extract in the exposed hardy fish can be exploited for effective aquaculture pond management against some unwanted predatory and weed aquatic organisms. However, the indiscriminate use of higher extract concentrations could seriously jeopardise the biodiversity of any aquatic environment. @JASEM
\end{abstract}

http://dx.doi.org/10.4314/jasem.v18i1.7

Aquaculture is the fastest growing food sector in the world, accounting for an estimated $43 \%$ of all fish consumed by humans globally (Allsopp et al., 2008). However, the presence of wild and unwanted organisms like frogs, molluscs, insect larvae and fish weeds is a common problem in extensive and semiextensive aquaculture (Edet and Ikpi, 2008). These organisms greatly decrease aquaculture productivity via predation and competition for available oxygen, food and habitat. Fish farmers tackled this problem with the use of synthetic chemicals, which are nonbiodegradable and accumulate in the environment to poses serious toxic threat to both targeted and nontargeted organisms (Randhawa and Kullar, 2011). This is unlike piscicidal plants that are bio-degradable and are more environmentally friendly with little or no residues (Stalin et al. 2008).

Adenium obesum is a typical piscicdal plant usually found throughout the Sahel region of Africa into Central Africa and the Arabia where it serves domestic, medicinal and toxicological purposes (Arbonnier, 2004; Oyen 2008). Clarias gariepinus is one of the many known predatory aquatic organisms because of its ability to cannibalise fish half its length or $10 \%$ of its own body weight (de Graaf and Janssen, 1996). The fish is also hardy in nature (Hengsawat et al. 1997) because of its possession of accessory breathing organs (Safriel and Bruton,
1984). Therefore, piscicidal plants that can kill the fish will inadvertently jeopardise the survival of some other co-inhabitant (predatory and/or weed organisms) of the same aquatic environment. This property can be meaningfully explored for effective aquaculture pond management prior to the stocking of desired fish species. Although A. obesum has been used to kill fish globally (Badwen-Davis 2010), information about its median lethal concentration is scanty thereby hampering attempts to establish baseline concentrations of its toxicity viz-a-viz that which results in total fish kill. Therefore, the study aimed to evaluate the toxicity of ethanol extract of $A$. obesum stem bark in African catfish, Clarias gariepinus.

\section{MATERIALS AND METHODS}

Plant Extraction and Preparation: Adenium obesum were collected from the open fields of Rurum town, Rano Local Government Area, Kano State, Nigeria between January - April, 2011 and authenticated at the Herbarium, Department of Biological Sciences, Ahmadu Bello University (A. B. U.), Zaria, Nigeria with Voucher No. 1386 by Mallam Musa Mohammed. The stem bark was removed, sun-dried and pounded into powder where $3.95 \mathrm{~kg}$ of it was extracted with $21 \mathrm{~L}$ of ethanol $(96.0 \%$ vol. SigmaAldrich $^{\circledR}$ Inc., St. Louis, MO 63178, USA) over a three-day (72-h) period to obtain a filtrate based on 
the maceration methods of Bentley (1977) and Ghani (1990), which was concentrated to dryness as described by Abu-Dahab and Afifi (2007).

Toxicity Bioassay: Adult Clarias gariepinus were purchased from a commercial catfish farm (Fannasson Investments Limited, Kano, Nigeria) and authenticated at the Fishery Section, Department of Biological Sciences, A. B. U., Zaria, Nigeria. Fish acclimatization lasted for 21 days under natural day and night photo-periods (12/12-h) with complete changing of pond water once in every three days. Fish were fed to their satisfaction (ad libitum) twice daily with $6 \mathrm{~mm}$ Coppens ${ }^{\circledR}$ fish feed for aquaculture (Coppens ${ }^{\circledR}$ International bv., 5700 AM Helmond, Holland). Mortality was used as an end point of toxicity and this was determined as described in the OECD guideline No. 203 (1992).

A total of 126 C. gariepinus $(265.50 \pm 4.03 \mathrm{~g}$ mean weight and $32.85 \pm 0.16 \mathrm{~cm}$ mean total length) were exposed to $6.25 \mathrm{mgL}^{-1}, 7.50 \mathrm{mgL}^{-1}, 8.20 \mathrm{mgL}^{-1}, 8.80$ $\mathrm{mgL}^{-1}$ and $10.00 \mathrm{mgL}^{-1}$ of the extract and a control in a static acute toxicity bioassay over a 96-h exposure period (OECD guideline No. 203, 1992) in triplicates. This is after the performance of a range finding test to determine the five extract concentrations as described by Fafioye (2001) and the control with no extract.

Median lethal concentration $\left(L C_{50}\right)$ determination: The median lethal concentration $\left(\mathrm{LC}_{50}\right)$ of the extract over the 96-h exposure period was determined using the Arithmetic method of Karber as adapted by Dede (1992) as follows:

LC50 $=$ LC100 $-\frac{\sum \text { Probit }}{\text { No. of fish per extract concentration }}$

Where $\mathrm{LC}_{100}=$ Extract concentration with $100 \%$ fish mortality.

Physicochemical analyses: The temperature, $\mathrm{pH}$, electrical conductivity and the total dissolved solids of the fish culture water were monitored with Hanna "Combo" portable hand instrument (Hi 98129, Hanna Instruments, Mauritius) while their dissolved oxygen content was monitored using the modified method of Winkler-Azide (Lind, 1979; APHA, 1985).

Statistical analyses: Data were expressed as mean $( \pm$ SEM) and subjected to ANOVA and Tukey's multiple comparison test for statistical significance at $\mathrm{p}<0.05$ using GraphPad software programme (GraphPad Prism, version 4.0, San Diego, California, USA.).

\section{RESULTS AND DISCUSSION}

The physicochemical parameters (temperature $24.65^{\circ} \mathrm{C}$; $\mathrm{pH}$ - 7.22; dissolved oxygen - $4.56 \mathrm{mgL}^{-1}$; total dissolved solids - $341.80 \mathrm{ppm}$ and electrical conductivity $-680.30 \mu \mathrm{Scm}^{-1}$ ) of the fish culture water were within acceptable limits for the growth and survival of C. gariepinus (Viveen et al., 1985; Peteri et al., 1992). Exposed fish showed signs of toxicity in terms of changed behaviours with adaptive responses, respiratory distress and nervous compromise, which were concentration and exposure period-dependent. Changed behaviours with adaptive responses were characterized by repeated attempts to jump out of fish culture water, erratic and uncoordinated movements, aggression and excessive mucous secretions. These responses were survival strategies by the exposed fish to escape from the toxic aquatic environment as well as coat body surfaces so as to prevent the continuous absorption of the toxicant within their culture water.

The respiratory distress was characterized by frequent opercula movements and air gulping with the continuous exposure of snouts above culture water levels. These were attempts to increase ventilation rates to compensate for low oxygen uptake (Fernandes and Mazon, 2003) by passing large volume of water over gill surfaces at faster rates (Reebs, 2009). This is in addition to the engagement of aerial mode of respiration so as to disengage gill respiration and by implication, prevent continuous gill contact with the toxicant. The respiratory distress might be due to gill epithelia damage or excessive mucous coating of gill epithelia surfaces (Tamse et al., 1995; Abalaka et al., 2010). The nervous compromise was initially characterized by hyperactivity and later, by increasing states of motionlessness, adoption of different postures, sudden darts, swirling/sluggish movements and loss of balance. These might be due to the acetylcholinesterase inhibition property of the plant as similar hyperactivity and uncoordinated movements and inhibited acetylcholinesterase activity was reported in ticks exposed to aqueous extract of $A$. obesum stem bark (Mgbojikwe, 2000).

The toxicity of the extract might have resulted in the mortality observed in some of the exposed fish, which was significantly $(\mathrm{p}<0.05)$ concentration and exposure period-dependent as was earlier reported in ticks by Mgbojikwe (2000). The low $\mathrm{LC}_{50}$ value of $7.35 \mathrm{mgL}^{-1}$ (Table 1) showed that the extract was toxic to the exposed fish as higher $\mathrm{LC}_{50}$ values signify less toxicity (Eisler and Gardener, 1993) and vice versa. The toxic nature of the $A$. obesum might be the reason behind the global use of the plant to poison fish (Oyen, 2008, Badwen-Davis, 2010), which can be exploited for effective aquaculture pond management prior to the stocking of the desired fish species. However, great care should be exercised in the use of the plant for this purpose as it might cause total fauna and flora destruction at concentrations higher and above the established $\mathrm{LC}_{50}$ value thereby interfering with the ecological balance of the aquatic environment.

\footnotetext{
${ }^{*}$ SAMSON ENEOJO ABALAKA; MUHAMMAD YAKASAI FATIHU; NAJUME DOGUWAR GIGINYA IBRAHIM; SULEIMAN FOLORUNSHO AMBALI
} 
Table 1: Determination of the median lethal concentration $\left(\mathrm{LC}_{50}\right)$ of ethanol extract of Adenium obesum stem bark in adult Clarias gariepinus over a 96-h exposure period based on the Arithmetic method of Karber (adapted by Dede, 1992).

\begin{tabular}{clllc}
\hline $\begin{array}{c}\text { Extract } \\
\begin{array}{c}\text { concentration } \\
\left(\mathrm{mgL}^{-1}\right)\end{array}\end{array}$ & $\begin{array}{l}\text { Concentration } \\
\text { differences }(\mathrm{A})\end{array}$ & $\begin{array}{l}\text { Mean } \\
\text { mortality }\end{array}$ & $\begin{array}{l}\text { Average } \\
\text { mean mortality } \\
(\mathrm{B})\end{array}$ & $\begin{array}{c}\text { Probit } \\
(\mathrm{A} \times \mathrm{B})\end{array}$ \\
\hline $0($ Control $)$ & 0 & 0.00 & 0.000 & 0.0000 \\
6.25 & 1.25 & 1.00 & 0.500 & 0.6250 \\
7.50 & 1.25 & 3.33 & 2.165 & 2.7063 \\
8.20 & 0.70 & 5.00 & 4.165 & 2.9155 \\
8.80 & 0.60 & 5.33 & 5.165 & 3.0990 \\
10.00 & 1.20 & 10.00 & 7.665 & 9.1980 \\
\hline \multicolumn{4}{c}{} \\
\hline
\end{tabular}

(B): average of the sum of preceding and proceeding mean mortality

$$
\begin{gathered}
\text { LC50 }=10-\frac{18.5438}{7} \\
=10-2.6491=7.3509 \\
\text { Therefore, } \text { LC }_{50}=7.35 \mathrm{mgL}^{-1}
\end{gathered}
$$

Conclusion: Ethanol extract of A. obesum can be effectively used in aquaculture pond management against some unwanted predatory and weed aquatic organisms as the plant is proven to be toxic to the hardy C. gariepinus.

\section{REFERENCES}

Abalaka, SE; Fatihu, MY; Ibrahim, NDG; Kazeem, HM (2010). Histopathological changes in the gills and skin of adult Clarias gariepinus exposed to ethanolic extracts of Parkia biglobosa pods. Basic Appl Pathol 3: 109-114.

Abu-Dahab, R; Afifi, F (2007). Anti-proliferative activity of selected medical plants of Jordan against a breast adenocarcinoma cell line (MCF7). Sci Pharm 75: 121-136.

Allsopp, M; Johnson, P; Santillo, D (2008). Challenging the aquaculture industry on sustainability: Technical overview. Greenpeace Research Laboratory Technical Note 01. Retrieved November 2, 2013, from Available from:

http://www.greenpeace.to/publications/Aquacult ure Report Technical.pdf

APHA (1985). Standard method for the examination of water and waste water. 15th ed. American Public Health Association, Washington DC, USA, p413-426.

Arbonnier, M (2004). Trees, shrubs and lianas of West African dry zones. CIRAD, MARGRAF Publishers, GMBH, MNHN, p161.

Bawden-Davies, J (2010). The Adenium species. Retrieved December 21, 2010, from http://www.ehow.com/about_6721472_adeniumspecies.html.
Bentley, AC (1977). Textbook of pharmaceutics. 8th ed. Bailliére Tindall, USA, p177-180.

Dede, EB (1992) Effect of Lindane pre-treatment on diclovors toxicity in vitro, in vivo. Ph.D Dissertation. Ahmadu Bello University, Zaria, Nigeria.

de Graaf, GT; Janssen, JAL (1996). Artificial reproduction and pond rearing of the African catfish, Clarias gariepinus in sub-saharan Africa: A handbook. FAO Fisheires Technical Paper 362, Rome, Italy, p1-73.

Edet, DI; Ikpi, GU (2008). Toxicity and behaviour of Clarias gariepinus (Burchell 1822) fingerlings subjected to piscicidal plant extract of Aidon tetrapleura tetrapleura. J Appl Sci Environ Manag 12 (3): 25-28.

Eisler, G; Gardener, R (1993). Acute toxicology to an estuarine teleost of mixtures of cadmium, copper and zinc salts. J Fish Biol 5: 131-142.

Fafioye, OO (2001). Lethal and sub-lethal effect of extracts of Parkia biglobosa and Rahpia vinifera on some fresh water fauna. Ph.D Dissertation. University of Ibadan, Nigeria, p216.

Fernandes, MN; Mazon, AF (2003). Environmental pollution and fish gill morphology. In: Val A.L. and Kapoor B.G. (eds.). Fish adaptations. Science Publisher, Enfield, USA, p203-231.

Ghani, A (1990). Introduction to pharmacognosy. 1st ed. Ahmadu Bello University Press Ltd., Zaria, Nigeria, p198.

Hengsawat, K; Ward, FJ; Jaruratjamon, P (1997). Effects of stocking densities on yield, growth and

\footnotetext{
${ }^{*}$ SAMSON ENEOJO ABALAKA; MUHAMMAD YAKASAI FATIHU; NAJUME DOGUWAR GIGINYA 
mortality of African catfish (Clarias gariepinus, Burchell 1882) cultured in cages. Aquaculture. 152: $67-76$.

Lind, OT (1979). A handbook of limnological methods. C.V. Mosby Co., St. Louis, USA, p199.

Mgbojikwe, LO (2000). Acaricidal properties of the aqueous stem bark extract of Adenium obesum. $\mathrm{PhD}$ Dissertation. University of Jos, Jos, Nigeria.

OECD (1992). Guidelines for the testing of chemicals No. 203: Fish acute toxicity test (adopted: $17^{\text {th }}$ July, 1992). Organisation for Economic Cooperation and Development Paris, France, Pp. 19.

Oyen, LPA (2008). Adenium obesum (Forssk.) Roem. \& Schult. In: Schmelzer G.H. and Gurib-Fakim A. (eds.). Plant resources of tropical Africa 11 (1): Medicinal Plant 1. PROTA

Foundation/Backhuys Publishers/CTA Wageningen, Netherlands, p46-49.

Peteri, A; Nandi, S; Chowdhury, SN (1992). Manual on seed production of African catfish (Clarias gariepinus). FAO document repository, BGD/87/045/92/22. Rome, Italy.

Randhawa, GK; Kullar, JS (2011). Bioremediation of pharmaceuticals, pesticides and petrochemicals with gomeya/cow dung. ISRN Pharmacology. doi: $\underline{10.5402 / 2011 / 362459}$
Reebs, SG (2009). Oxygen and fish behaviour. Retrieved October 28, 2012, from http://www.howfishbehave.ca/pdf/oxygen.pdf

Safriel, O; Bruton, MN (1984). A comparative aquaculture research programme for South Africa. South African National Scientific Programme Report 89. CSIR, Pretoria, p79.

Stalin, SI; Kiruba, S; Das, SSM (2008). A comparative study in the toxicity of a synthetic pyrethroid Deltamethrin and a neem based pesticide Azadirachtin to Poecilia reticulate Peters 1859 (Cyprinodontiformes: Poeciliidae). Turk J Fish Aquat Sci 8: 1-5.

Tamse, CT; Gacutan, RQ; Tamse, AF (1995). Changes induced in the gills of milkfish (Chanos chanos Forskal) fingerlings after acute exposure to Nifurpirinol (Furanace; P-7138). Bull Environ Contam Toxicol 54: 591-596.

Viveen, WJAR; Rither, CJJ; van Oordt, PGJ; Janssen, JAL; Huisman, EA (1985). Practical manual for the culture of the African catfish (Clarias gariepinus). Directorate General for International Technical Cooperation, The Hague, Netherlands, p93.

\footnotetext{
${ }^{*}$ SAMSON ENEOJO ABALAKA; MUHAMMAD YAKASAI FATIHU; NAJUME DOGUWAR GIGINYA 